\title{
Tokyo deans plan flexible future for students
}

Keiko Kandachi, Tokyo

Undergraduates at the University of Tokyo will have unprecedented freedom to switch between the sciences and the humanities, under a reform package that is due to take effect in three years' time. The move, which will be announced in March, is seen as a harbinger of change in Japan's notoriously inflexible higher-education system.

At the moment, it is difficult for students at Japan's most prestigious university to change their academic course after admittance. But the university's deans recently agreed to reforms that will allow science undergraduates to transfer to law, for example, at the end of their second year of study. Each department will accept a certain percentage of students from any academic track, based on their grades in their first two years.

The idea is to give students enough leeway to do what really interests them, explains Atsushi Koma, the university's vice-president. It is also aimed at meeting a growing demand for graduates who are well-versed in both sciences and the humanities to work in business, law, government and academia.

Under the plan, each department will require students to have attended prerequisite classes before transferring. The university promises to notify students of these requirements early enough for them to make a smooth transfer and graduate within the regular time frame.

In a bid to give students more freedom of choice, the university will introduce several associated measures, including a lecture series about new developments in the sciences and humanities, to help students to identify their true interests. The university will also introduce a financial-aid plan for outstanding students.

Koma says that in his experience as a chemistry professor, current restrictions stifle students by forcing them to persevere with topics they don't like. He adds that even students that move on to postgraduate work often lack a real passion for their subject area, and so avoid challenging choices of subject for their theses. The reforms will encourage students to take classes in more subjects, so they find out what intrigues them, Koma says.

But Masakata Ogawa, a professor of science and technology education at Kobe University, says that students will need much better career-planning advice than they get at the moment if they are to take advantage of a more flexible course structure.

Students are also voicing scepticism about the change. "Before the university introduces the reforms, I want it to make sure that each professor is more committed to teaching," says one science student, who did not want to be identified. "Some professors seem to focus on research and lack the energy needed to teach undergraduates."

But education experts say that the initiative will probably lead the way for Japan's

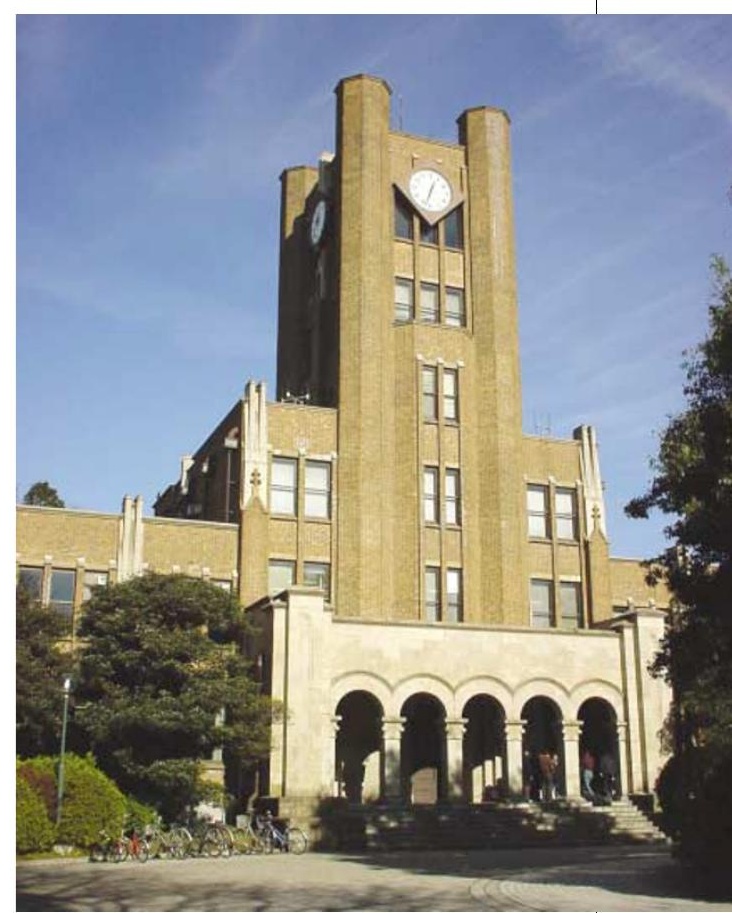

Officials at the University of Tokyo hope reforms will ignite some passion in the student body.

other universities. "The innovation at the nation's top institution is likely to become a model for the Japanese university system," says Masamichi Ishii, a senior research fellow at the National Institute of Science and Technology Policy in Tokyo.

\section{Transgenic salmon still out in the cold in United States}

\section{Hannah Hoag, Washington}

Approval for the commercial farming of transgenic salmon in the United States remains at least 18 months off, say officials at Aqua Bounty Farms in Waltham, Massachusetts, the only company that has filed for approval to produce them.

The progress of the application, made by Aqua Bounty Farms in November 1996, has been watched avidly by advocates of transgenic technology - including researchers hoping to develop their own genetically modified fish - who had hoped that the Food and Drug Administration (FDA) would have given its approval by now (see Nature 406, 10-12; 2000).

Critics of the technology point to the unknown risks posed by a possible escape of the fish from their farms, perhaps leading to competition with wild fish for food, the introduction of transgenes into wild fish, and even possible collapse of wild fish populations.

Joseph McGonigle, vice-president of
Aqua Bounty Farms, says that he doesn't expect the FDA to approve the application until late 2004. The company plans to submit a second application, for transgenic trout, in about a year's time.

McGonigle says that the delay is placing the company under financial strain. "Money's an issue now," he says. "We've been living on venture capital for years."

But a report issued last week by the non-profit Pew Initiative on Food and Biotechnology questioned the FDA's ability to regulate transgenic fish properly. It says that the FDA lacks the expertise to evaluate environmental risks. The report also calls for greater transparency and public involvement in the review process.

Aqua Bounty's Atlantic salmon carry a gene construct of the growth-hormone gene from Pacific chinook salmon, and a promoter sequence from the ocean pout for the production of antifreeze proteins. They grow twice as fast as most farmed salmon but consume less food. The company is working with the Harvard Center for Risk Analysis to perform an environmentalimpact assessment, which it will use to support its application.

Meanwhile, Chinese researchers have been working with fast-growing transgenic carp since the late 1980s, and Cuba is considering commercialization of tilapia that were first bred there in 1993. The Cuban researchers say it will be three years before they know the regulatory fate of their tilapia.

Mario Estrada, leader of the aquaticorganism project at the Center for Genetic Engineering and Biotechnology in Havana, says that most of the food-safety studies are done, including an experiment in which tilapia were eaten by volunteers.

Researchers elsewhere are working with transgenes that will resist bacterial or viral infection. "Disease is one of the biggest issues in raising fish in aquaculture," says Bill Muir, a professor of genetics at Purdue University in West Lafayette, Indiana. http://pewagbiotech.org/research/fish 